\title{
Isolation, in vitro and in silico Evaluation of Phenylethanoid Glycoside from Arrabidaea brachypoda as Lipoxygenase Inhibitor
}

\author{
Camila S. Bertanha, ${ }^{a}$ Valéria M. M. Gimenez, ${ }^{a}$ Ricardo A. Furtado, ${ }^{a}$ Denise C. Tavares, ${ }^{a}$ \\ Wilson R. Cunha, ${ }^{a}$ Márcio L. A. e Silva, ${ }^{\circledR a}$ Ana H. Januario, ${ }^{\circledR a}$ Alexandre Borges, ${ }^{b}$ \\ Daniel F. Kawano, ${ }^{b}$ Renato L. T. Parreira ${ }^{\circledR a}$ and Patrícia M. Pauletti ${ }^{\circledR} * a$ \\ ${ }^{a}$ Núcleo de Pesquisa em Ciências Exatas e Tecnológicas, Universidade de Franca (UNIFRAN), \\ Av. Dr. Armando Salles Oliveira, 201, 14404-600 Franca-SP, Brazil \\ ${ }^{b}$ Faculdade de Ciências Farmacêuticas, Universidade Estadual de Campinas (Unicamp), \\ Rua Cândido Portinari 200, 13083-871 Campinas-SP, Brazil
}

\begin{abstract}
Lipoxygenase (LOX) plays an important role in inflammatory processes and Arrabidaea brachypoda (DC.) Bureau (Bignoniaceae) has been described as presenting antiinflammatory activity. Therefore, the objective of this study was to develop a high-performance liquid chromatography (HPLC) procedure to directly recognize LOX inhibitor compounds in A. brachypoda crude extract, facilitating the isolation, characterization of bioactive compounds, evaluation of natural compounds using an in vitro 15-LOX assay and prediction of the most probable binding modes of their main constituent through molecular docking simulations. The chemical analysis was performed by ethanol crude extract microfractionation using HPLC-DAD (diode array detector) associated to a fraction collector. The bioactive chromatogram displayed a peak with 50.9\% LOX inhibition at 13.6 min retention time. The extract was purified and conandroside was isolated, presenting a LOX inhibitory activity with an inhibitory concentration $\left(\mathrm{IC}_{50}\right)$ of $7.8 \pm 1.1 \mu \mathrm{M}$, close to standard quercetin $\left(\mathrm{IC}_{50} 7.6 \pm 0.3 \mu \mathrm{M}\right)$. Additionally, conandroside was not cytotoxic to normal cells (GM07492A). The LOX-conandroside complex displayed a slightly higher docking score (92.7) than quercetin (71.5). These results together suggest that conandroside could be explored as lipoxygenase inhibitor.
\end{abstract}

Keywords: Arrabidaea brachypoda, 15-lipoxygenase, conandroside, anti-inflammatory activity, cytotoxic activity

\section{Introduction}

Arrabidaea brachypoda (DC.) Bureau, synonym Fridericia platyphylla (Cham.) L.G. Lohmann, is found in the region of Brazilian Cerrado and is known as "cipó-una" and "cervejinha-do-campo". This species is commonly used in traditional medicine for treatment of kidney stones and painful joints. ${ }^{1-4}$ Arrabidaea genus belongs to the Bignoniaceae family, which includes 800 species distributed from the south of United States of America to the north of Chile and Argentina. ${ }^{5-7}$ Countless biological activities have been described for this genus, such as antiviral against human herpes virus 1 and Dengue virus 2, as well as healing, antimicrobial, anti-inflammatory,

*e-mail: patricia.pauletti@unifran.edu.br antiangiogenic, antitumoral, antioxidant, schistosomicidal and lipoxygenase inhibitor properties. ${ }^{8-17}$

Lipoxygenases (LOXs) are dioxygenases that metabolize arachidonic acid during the inflammatory process, producing lipid mediators which are known as eicosanoids. Lipoxygenases have shown to possess specific roles in various human pathologies due to its central participation in leukotriene biosynthesis. Lipoxygenases and leukotrienes are involved in the pathogenesis of inflammatory diseases, such as asthma, rhinitis, rheumatoid arthritis, psoriasis, dermatitis, nephritis, atherosclerosis and cancer. ${ }^{18}$

High-performance liquid chromatography (HPLC) hyphenated with diode array detector (DAD), high resolution mass spectrometry (HRMS) and bioassay are important tools that may be used in qualitative analysis of crude plant extract investigations to facilitate the discovery 
of bioactive compounds and to better characterize herbal medicines. ${ }^{19}$

Thus, considering the ethnopharmacological use of the species and the necessity of simplifying the isolation process, the aims of this study were to develop a procedure to directly recognize the bioactive compounds in crude herbal extracts, contributing for rapid isolation, chemical characterization, subsequent biological evaluation using an in vitro 15-LOX assay and prediction of the most probable binding modes of their main constituents through molecular docking simulations.

\section{Experimental}

\section{General}

Nuclear magnetic resonance (NMR) spectra were recorded in $\mathrm{CD}_{3} \mathrm{OD}$ on a Bruker AVANCE DRX 500 spectrometer, using tetramethylsilane (TMS) as internal standard. The analytical and preparative HPLC separation were carried out on Shimadzu LC-6AD systems equipped with a DGU-20A5 degasser, a UV-Vis detector series SPD-20A or a DAD detector series SPD-M20A, a communication bus module CBM-20A and a Rheodyne manual injector. Methanol used in the experiments was HPLC grade (J.T. Baker, Ecatepec, Mexico). Direct-Q UV3 system, Millipore (Billerica, USA), furnished ultrapure water. Silica gel C18 (Fluka, 230-400 mesh) was employed during the solid phase extraction. Analytical and semi-preparative separations were performed on a Phenomenex Onyx monolithic C18 column $(100 \times 4.60 \mathrm{~mm}$ and $100 \times 10 \mathrm{~mm})$ attached to a pre-column. Quercetin (purity $\geq 95 \%$ ) was obtained from Sigma-Aldrich (St. Louis, MO, USA).

\section{Plant material}

The aerial parts of Arrabidaea brachypoda (DC.) Bureau (Bignoniaceae) were harvested in the region of Brazilian Cerrado in Luiz Antonio, state of São Paulo, in June 2013. The material was identified by Valeria M. M. Gimenez. A voucher specimen (SPFR16258) was deposited in the Herbarium of the Department of Biology, Laboratory of Plant Systematics, Faculdade de Filosofia Ciências e Letras of Ribeirão Preto, University of São Paulo, Brazil (Herbarium, SPFR).

\section{Extraction}

After dried, the branches (121 g) were powered and extracted with ethanol at room temperature. The solution was filtered and the solvent removed under reduced pressure to yield $2 \mathrm{~g}$ of crude extract.

\section{Microfractionation}

The ethanol crude extract from Arrabidaea brachypoda (DC.) Bureau (Bignoniaceae) (10.1 mg) branches was dissolved in $1 \mathrm{~mL}$ of $\mathrm{CH}_{3} \mathrm{OH}-\mathrm{H}_{2} \mathrm{O}(5: 95, \mathrm{v} / \mathrm{v})$ and subsequently submitted to microfractionation by HPLC-DAD with a semi-preparative $\mathrm{C} 18$ column (Onix Monolithic, $100 \times 10 \mathrm{~mm}$ ), eluted with $\mathrm{CH}_{3} \mathrm{OH}-\mathrm{H}_{2} \mathrm{O}$ $(+0.1 \%$ acetic acid $)$ in gradient mode $\left(5-100 \% \mathrm{CH}_{3} \mathrm{OH}\right.$ in $30 \mathrm{~min}, 4 \mathrm{~mL} \mathrm{~min}^{-1}$ flow). The microfractions were collected every $30 \mathrm{~s}$ using a fraction collector (Frac-920, GE) and dried in a Speedvac concentrator Savant SPD 2010 (Thermo). The fractions were dissolved in $500 \mu \mathrm{L}$ of a solution (dimethyl sulfoxide (DMSO)-LOX inhibitor screening assay buffer $1: 4 \mathrm{v} / \mathrm{v}$ ) and $30 \mu \mathrm{L}$ evaluated in the in vitro 15 -LOX inhibitory assay.

\section{HPLC-HRMS analysis}

The crude extract $\left(2 \mathrm{mg} \mathrm{mL}^{-1}\right.$ in $\left.\mathrm{CH}_{3} \mathrm{OH}\right)$ was analyzed by HPLC-HRMS using a micrOTOF-Q II - ESI-TOF Mass Spectrometer (Bruker Daltonics), Shimadzu HPLC system with an LC 20 AD pump, automatic injection SIL20AHT, DAD (200-600 nm) detector and using a C18 column (Phenomenex ${ }^{\oplus}$ Luna, $5 \mu \mathrm{m}, 250 \times 4.6 \mathrm{~mm}$ ). HRMS data were obtained using: $3.5 \mathrm{kV}$ capillary voltage, $220{ }^{\circ} \mathrm{C}$ dry temperature, $60 \mathrm{psi}$ nebulizer gas, $10 \mathrm{~L} \mathrm{~min}^{-1}$ dry gas, 50-1300 Da mass range and nitrogen as drying, nebulizing and collision gas. The mobile phase was a linear gradient from $95 \% \mathrm{H}_{2} \mathrm{O} / 0.1 \%$ acetic acid (solvent $\mathrm{A}$ ) and $5 \% \mathrm{CH}_{3} \mathrm{OH}$ (solvent $\mathrm{B}$ ) to $100 \%$ solvent $\mathrm{B}$ over $35 \mathrm{~min}$ followed by $10 \mathrm{~min} 100 \%$ solvent $\mathrm{B}$, with $1.0 \mathrm{~mL} \mathrm{~min}^{-1}$ flow rate. All analyses were processed using the Bruker Daltonics Data Analysis 4.3 software.

Isolation

After identification of the retention time $\left(t_{R}\right)$ of the compound which showed biological activity, the ethanol crude extract (1.7 g) was fractionated by solid phase extraction-octadecylsilane (SPE-ODS) with $\mathrm{CH}_{3} \mathrm{OH}-\mathrm{H}_{2} \mathrm{O}$ in the following proportions: 30,50 and $100 \% \mathrm{CH}_{3} \mathrm{OH}$. The $50 \% \mathrm{CH}_{3} \mathrm{OH}$ fraction (170 mg) was purified by semipreparative HPLC-DAD using $\mathrm{CH}_{3} \mathrm{OH}-\mathrm{H}_{2} \mathrm{O}(30: 70$, v/v), semi-preparative $\mathrm{C} 18$ monolithic column, $\mathrm{UV}$ detection at $254 \mathrm{~nm}$ and flow rate of $4 \mathrm{~mL} \mathrm{~min}^{-1}$, yielding compound 1 (9.8 mg, $\left.\mathrm{t}_{\mathrm{R}} 9.65 \mathrm{~min}\right)$. 


\section{Conandroside (1)}

A foam, $\mathrm{CH}_{3} \mathrm{OH}$, purity of $94 \%$; ${ }^{1} \mathrm{H}$ NMR $(500 \mathrm{MHz}$, $\left.\mathrm{CD}_{3} \mathrm{OD}\right) \delta 7.56\left(1 \mathrm{H}, \mathrm{d}, J 15.6 \mathrm{~Hz}, \mathrm{H}-7^{\prime}{ }^{\prime \prime}\right), 7.06(1 \mathrm{H}, \mathrm{d}$, $J 2.0 \mathrm{~Hz}, \mathrm{H}-2$ "'), 6.96 (1H, dd, $J 2.0$ and $8.0 \mathrm{~Hz}, \mathrm{H}-6$ "'), $6.79(1 \mathrm{H}, \mathrm{d}, J 8.0 \mathrm{~Hz}, \mathrm{H}-5$ "'), $6.70(1 \mathrm{H}, \mathrm{d}, J 2.0 \mathrm{~Hz}, \mathrm{H}-2)$, $6.68(1 \mathrm{H}, \mathrm{d}, J 8.0 \mathrm{~Hz}, \mathrm{H}-5), 6.57(1 \mathrm{H}, \mathrm{dd}, J 2.0$ and $8.0 \mathrm{~Hz}$, H-6), 6.26 (1H, d, J 15.6 Hz, H-8'”), 4.95 (1H, m, H-4'), $4.44(1 \mathrm{H}, \mathrm{d}, J 7.5 \mathrm{~Hz}, \mathrm{H}-1$ '), 4.42 (1H, d, J 7.5 Hz, H-1'), $4.04(1 \mathrm{H}, \mathrm{m}, \mathrm{H}-8), 3.83\left(1 \mathrm{H}, \mathrm{t}, J 9.0 \mathrm{~Hz}, \mathrm{H}-3^{\prime}\right), 3.72(1 \mathrm{H}$, m, H-8), 3.63 (2H, m, H-6' and H-5"), 3.54 (2H, m, H-5' and $\left.\mathrm{H}^{-6}{ }^{\prime}\right), 3.48\left(1 \mathrm{H}, \mathrm{dd}, J 9.0\right.$ and $\left.8.0 \mathrm{~Hz}, \mathrm{H}-2^{\prime}\right), 3.34(1 \mathrm{H}$, m, H-4"), 3.27 (1H, t, J 9.0 Hz, H-3"), 3.14 (1H, dd, J 7.6 and $8.9 \mathrm{~Hz}, \mathrm{H}-2$ "), 3.07 (1H, t, $J 10.8 \mathrm{~Hz}, \mathrm{H}-5$ "), 2.79 $(2 \mathrm{H}, \mathrm{m}, \mathrm{H}-7) ;{ }^{13} \mathrm{C}$ NMR $\left(125 \mathrm{MHz}, \mathrm{CD}_{3} \mathrm{OD}\right) \delta 168.4(\mathrm{C}$, C-9"”), 149.7 (C, C-4"”), 147.2 (CH, C-7"”), 146.9 (C, C-3"'), 146.1 (C, C-3), 144.7 (C, C-4), 131.4 (C, C-1), 127.8 (C, C-1"”), 123.0 (CH, C-6"”), 121.3 (CH, C-6), 117.1 (CH, C-2), 116.6 (CH, C-5"'), 116.3 (CH, C-5), 115.1 (CH, C-8"'), 115.0 (CH, C-2"'), 106.8 (CH, C-1"), 103.9 (CH, C-1'), 85.2 (CH, C-3'), 77.6 (CH, C-3”), 75.9 (CH, C-5'), 75.7 (CH, C-2”), $74.9\left(\mathrm{CH}, \mathrm{C}-2\right.$ '), $72.2\left(\mathrm{CH}_{2}\right.$, C-8), 71.0 (CH, C-4"), 70.8 (CH, C-4'), $67.3\left(\mathrm{CH}_{2}, \mathrm{C}-5\right.$ "), $62.3\left(\mathrm{CH}_{2}, \mathrm{C}-6\right.$ ') $36.5\left(\mathrm{CH}_{2}, \mathrm{C}-7\right)$; HRMS $\mathrm{m} / z$, calcd. for $\mathrm{C}_{28} \mathrm{H}_{33} \mathrm{O}_{15}[\mathrm{M}-\mathrm{H}]^{-}:$: 609.1819, found: 609.1743; calcd. for $\mathrm{C}_{28} \mathrm{H}_{34} \mathrm{NaO}_{15}[\mathrm{M}+\mathrm{Na}]^{+}$: 633.1795, found: 633.1796. The NMR spectra were identical to the previously reported data. ${ }^{20}$

\section{In vitro 15-lipoxygenase inhibitory activity assay}

The ability of the ethanol crude extract, microfractions, quercetin, and conandroside in inhibiting 15-LOX was evaluated using an in vitro enzyme assay kit (Catalog No. 760700, Cayman Chemical, Ann Arbor, MI, USA) according to the instructions of the manufacturer. The stock solutions ( 2 and $1 \mathrm{mg} \mathrm{mL}^{-1}$ ) were prepared in the assay buffer and DMSO (8:2 v/v), and then diluted with the LOX inhibitor screening assay buffer to the assayed concentrations (extract: $25 \mu \mathrm{g} \mathrm{mL}^{-1}$, compounds: $1.25-80 \mu \mathrm{M})$. The procedure was developed as described in our earlier study. ${ }^{17}$

\section{In vitro cytotoxicity assay}

The cytotoxic activity was assessed using the in vitro Toxicology Colorimetric Assay Kit (XTT; Roche Diagnostics) according to the manufacturer's protocol with normal human lung fibroblasts (GM07492A). The assay was performed as previously described. ${ }^{17}$ The stock solutions were obtained by dissolving the samples in water at $1 \%$ DMSO.

\section{Molecular docking simulations}

The docking studies were performed in GOLD 5.3 $3^{21,22}$ for conandroside and quercetin (control) using the 3-D structure of human 15-lipoxygenase-2 in complex with tetraethylene glycol monooctyl ether (C8E4), as substrate mimic (PDB ID: 4NRE). Simulations were performed with default parameters using a $10 \AA$ docking sphere, for which the ligands and water molecules were preserved, and the best poses subsequently scored using the GoldScore fitness function. ${ }^{23}$ Redocking was used for docking validation, with a resulting heavy atom root-mean-squared deviation of $1.7 \AA$, which was assumed as acceptable considering the number of freely rotating bonds (18) in the redocked ligand. ${ }^{24}$ Analyses of the best poses and their corresponding intermolecular interactions were performed in Discovery Studio 2016. ${ }^{25}$

\section{Results and Discussion}

The ethanol crude extract from Arrabidaea brachypoda (DC.) Bureau (Bignoniaceae) branches presented $49.4 \pm 2.5 \%$ inhibitor concentration required for $50 \%$ inhibition of $15-\mathrm{LOX}\left(\mathrm{IC}_{50}\right)$ at $25 \mu \mathrm{g} \mathrm{mL} \mathrm{m}^{-1}$, as shown in Table 1. This result, when compared to that obtained for the crude extract of Cuspidaria pulchra (Cham.) L.G.Lohmann (Bignoniaceae), indicates a promising activity. ${ }^{17}$ Additionally, the crude extract roots of Arrabidaea brachypoda (DC.) Bureau (Bignoniaceae) presented in vivo anti-inflammatory activity. ${ }^{4}$ The extract was also evaluated against a normal cell line (GM07492A, human lung fibroblasts) and exhibited a cytotoxic concentration $\left(\mathrm{CC}_{50}\right)$ of $2,352.0 \pm 28.5 \mu \mathrm{g} \mathrm{mL}^{-1}$, and was thus considered not cytotoxic, according to reference values..$^{26}$

The bioactive ethanol crude extract $\left(10.1 \mathrm{mg} \mathrm{mL}^{-1}\right)$ was dissolved in methanol-water $(5: 95 \mathrm{v} / \mathrm{v})$ and $1 \mathrm{~mL}$ was subjected to HPLC on a semi-preparative C18 column in a

Table 1. 15-LOX inhibitory and cytotoxic activities of Arrabidaea brachypoda (DC.) Bureau (Bignoniaceae) ethanol extract, conandroside and quercetin

\begin{tabular}{lcc}
\hline Sample & $\begin{array}{c}\mathrm{IC}_{50}(\text { mean } \pm \mathrm{SD})^{\mathrm{a}} / \\
\mu \mathrm{M}\end{array}$ & $\begin{array}{c}\mathrm{CC}_{50}(\text { mean } \pm \mathrm{SD})^{\mathrm{b}} / \\
\mu \mathrm{M}\end{array}$ \\
\hline Crude ethanolic extract & $49.4 \pm 2.5^{\mathrm{c}}$ & $2,352.0 \pm 28.5 \mu \mathrm{g} \mathrm{mL}^{-1}$ \\
Conandroside & $7.8 \pm 1.1$ & $>2,500$ \\
Quercetin & $7.6 \pm 0.3$ & - \\
\hline
\end{tabular}

The experiments were performed in triplicate. ${ }^{\text {anhibitor concentration }}$ required for $50 \%$ inhibition of $15-\mathrm{LOX}$; ${ }^{\mathrm{b}}$ cytotoxic concentration for GM07492A cell line (human lung fibroblasts); 'percentage of 15-LOX inhibition at $25 \mu \mathrm{g} \mathrm{mL}^{-1}$. Doxorubicin was used as a positive control $\left(\mathrm{CC}_{50}=0.5 \pm 0.2 \mu \mathrm{g} \mathrm{mL}^{-1}\right)$. 

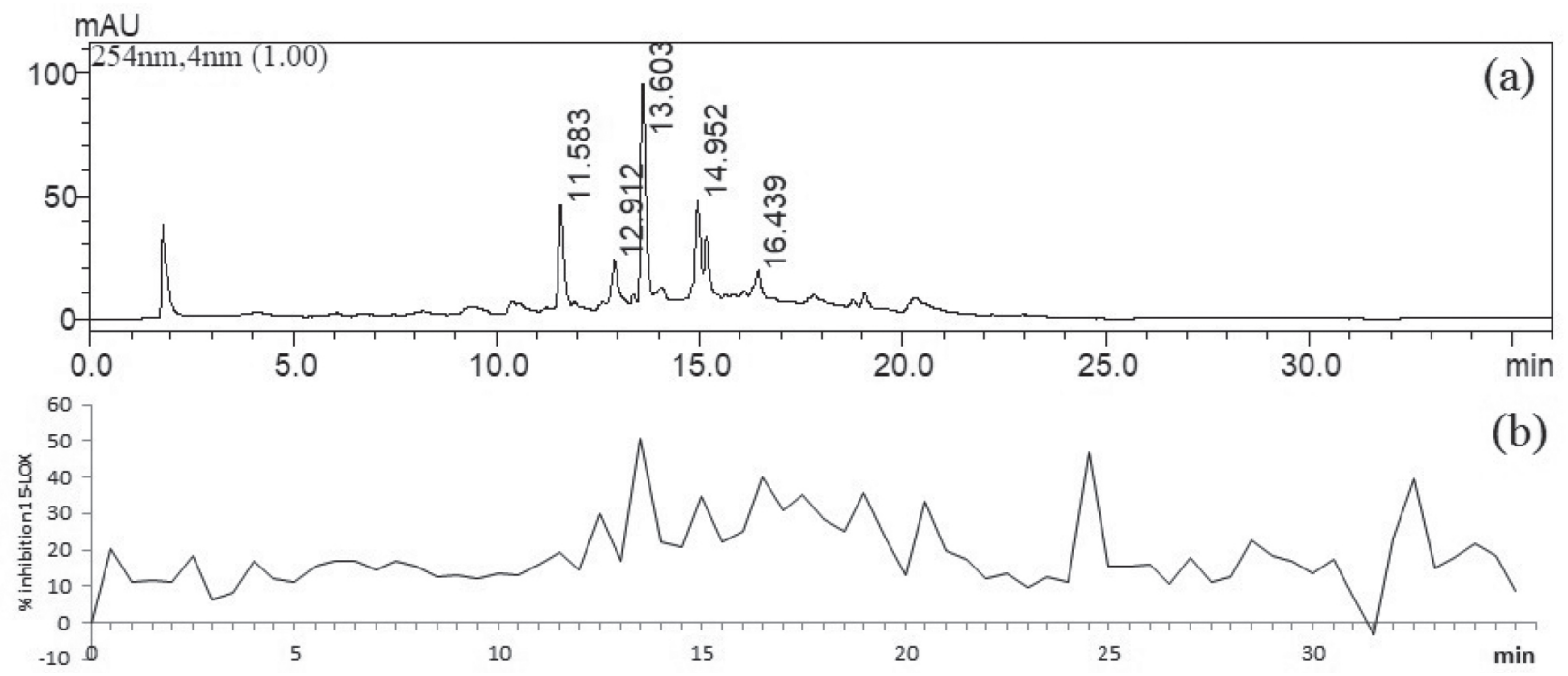

Figure 1. HPLC chromatogram of the ethanol extract from Arrabidaea brachypoda (DC.) Bureau (Bignoniaceae) branches. (a) DAD detection at $254 \mathrm{~nm}$ and (b) 15-LOX inhibitory activity of the microfractions, at $100 \mu \mathrm{g} \mathrm{mL}^{-1}$, collected during HPLC analysis.

linear gradient program with methanol-water $(+0.1 \%$ acetic acid) starting with a methanol initial concentration of $5 \%$ that increased up to $100 \%$ over $30 \mathrm{~min}$, then $5 \min 100 \%$ methanol. A total of 70 microfractions were collected and evaluated in the in vitro 15-LOX inhibitory assay. The percentage of inhibition, obtained in the assay, allow us to generate a bioactivity chromatogram that was compared with the chromatogram at $\lambda 254 \mathrm{~nm}$ (Figure 1). The comparison of both chromatograms indicates that the chromatographic band with 50.9\% 15-LOX inhibitory activity was observed at 13.6 min retention time.

The ethanol crude extract was also analyzed by HPLC-HRMS and the peak at 19.1 and $19.3 \mathrm{~min}$, in negative and positive mode, $\mathrm{m} / \mathrm{z} 609.1743[\mathrm{M}-\mathrm{H}]^{-}$ and $m / z 633.1796[\mathrm{M}+\mathrm{Na}]^{+}$suggest the presence of conandroside (1, Figure 2 ) as the main bioactive compound, and which was afterwards isolated and its structure confirmed using ${ }^{1} \mathrm{H}$ and ${ }^{13} \mathrm{C}$ NMR data.

Conandroside (1, Figure 2) is a natural product with a phenylethanoid glycoside skeleton isolated from several species such as Conandron ramoidioides Siebold \& Zucc. (Gesneriaceae), Sanango racemosum (Ruiz \& Pav.) Barringer (Gesneriaceae), Polypremum procumbens L. (Tetrachondraceae) and Mimulus guttatus DC. (Phyrmaceae)..$^{20,27-29}$ Its chemical structure resembles verbascoside (2, Figure 2), which was isolated by our group from Cuspidaria pulchra, a synonym of Arrabidaea pulchra. Verbascoside presented 15-LOX inhibitory activity with an $\mathrm{IC}_{50}$ value of $1.76 \pm 0.25 \mu \mathrm{M} \cdot{ }^{17}$ Both compounds differ in their second carbohydrate unity, which is xylose in conandoside and rhamnose in verbascoside. Evaluation of the inhibitory activity of conandroside on 15-LOX (Table 1) showed an $\mathrm{IC}_{50}$ value of $7.8 \pm 1.1 \mu \mathrm{M}$, similar to quercetin's

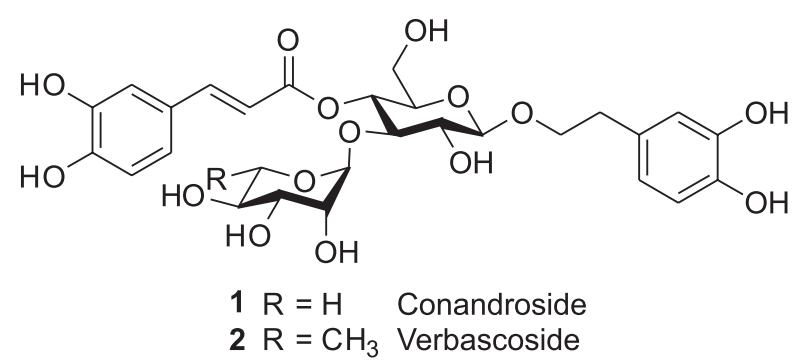<smiles>O=c1c(O)c(-c2ccc(O)c(O)c2)oc2cc(O)cc(O)c12</smiles>

3 Quercetin

Figure 2. Structures of conandroside (1), verbascoside (2) and quercetin (3).

$\mathrm{IC}_{50}$ value of $7.6 \pm 0.3 \mu \mathrm{M}(\mathbf{3}$, Figure 2$)$, a flavonoid with anti-inflammatory properties. ${ }^{30}$ Furthermore, conandroside was unable to affect human lung fibroblasts cells at assayed concentrations $\left(\mathrm{CC}_{50}>2,500 \mu \mathrm{M}\right)$. This is the first report of conandroside as LOX inhibitor.

Considering the similar 15-LOX inhibition profiles observed for conandroside and quercetin, molecular docking simulations were performed to predict the probable binding modes of these compounds at the binding site of 15-LOX, isoform 2 (Figure 3a). Such analyses involved the inspection of intermolecular interactions with the most relevant amino acid residues involved in ligand binding, both directly or through the use of water molecules, and coordination (or not) with $\mathrm{Fe}^{3+}$ ion at the active site of 15-LOX-2. ${ }^{31,32}$ 


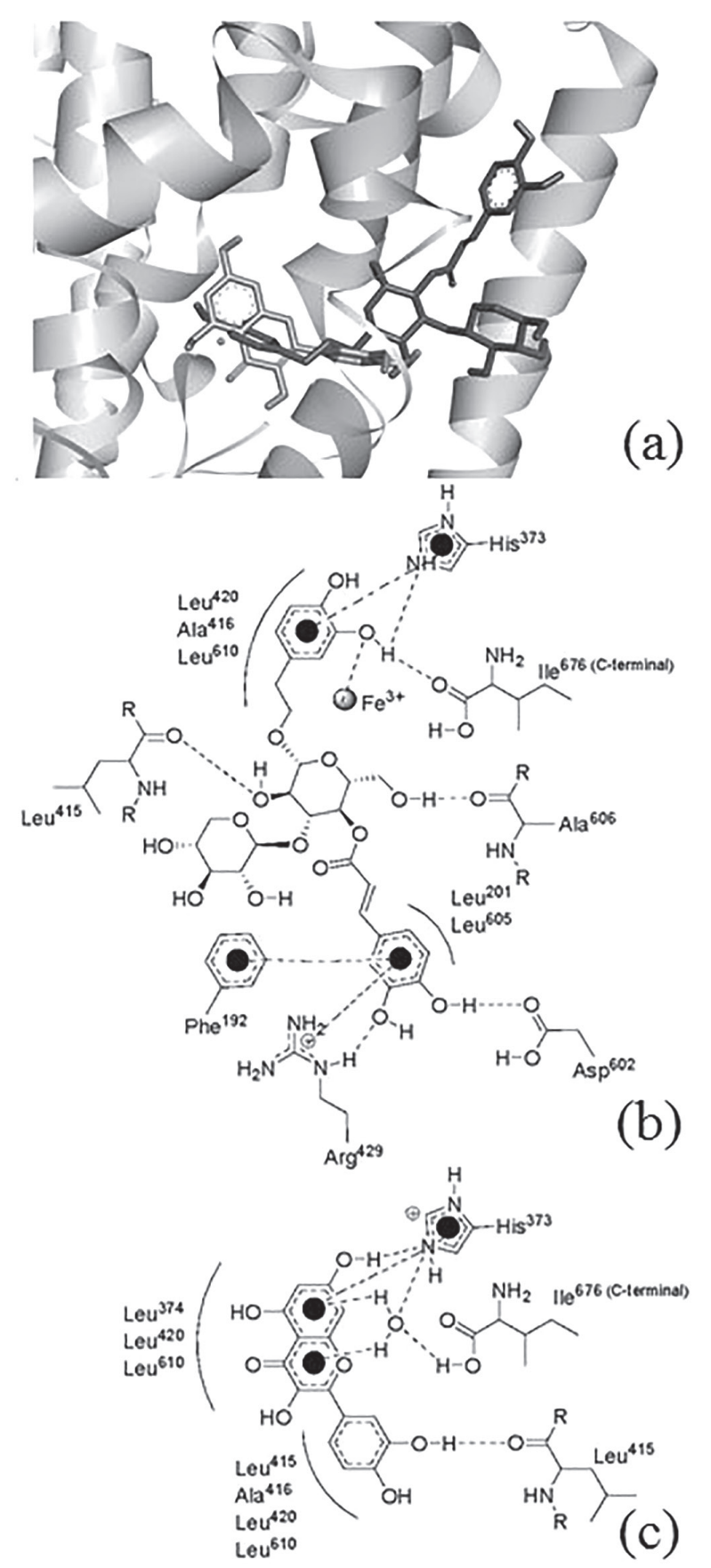

Figure 3. Comparisons between the binding modes of conandroside and quercetin at the active site of 15-LOX, isoform 2. (a) Docked poses of conandroside (dark gray) and quercetin (light gray); two-dimensional diagrams of the ligand-protein interactions for (b) conandroside and (c) quercetin. Dashed lines correspond to hydrogen bonds or $\pi-\pi /$ cation- $\pi$ interactions (in these cases, aromatic features are indicated with black circles) while solid arches highlight the hydrophobic interactions.

In this regard, the LOX-conandroside complex displayed a slightly higher docking score (92.7) than the observed for quercetin (71.5). Analysis of the interaction pattern for conandroside (Figure $3 b$ ) highlighted the existence of hydrogen bonds among one of the hydroxyl groups at catecholic ether moiety with $\mathrm{His}^{373}$ and Ile ${ }^{676}$, and also the coordination of this group with $\mathrm{Fe}^{3+}$ ion at the active site, which are considered pivotal interactions for enzyme inhibition and for the subsequent interference in the redox cycle of $15-\mathrm{LOX}-2 .{ }^{30,33} \mathrm{His}^{373}$ residue also performs a $\pi-\pi$ interaction with the same aromatic ring of conandroside while the other catechol ring is involved in an $\mathrm{H}$-bond with $\mathrm{Asp}^{602}$, an $\mathrm{H}$ bond and a cation- $\pi$ interaction with $\operatorname{Arg}^{429}$ and a $\pi-\pi$ interaction with Phe ${ }^{192}$. The glucosyl moiety also displays hydrogen bonds with $\mathrm{Leu}^{415}$ and $\mathrm{Ala}^{606}$.

For quercetin (Figure 3c), the main interactions would correspond to an $\mathrm{H}$-bond involving the catecholic ring with $\mathrm{Leu}^{415}$, a H-bond, $\pi-\pi$ and cation- $\pi$ interaction with $\mathrm{His}^{373}$, and an indirect $\mathrm{H}$-bond using a water molecule as bridge to connect its benzopyrone nucleus of the ligand with $\mathrm{His}^{373}$ and $\mathrm{Ile}^{676}$ from the active site. Although quercetin displays fewer (stronger) hydrogen bond interactions when compared to conandroside, its compact structure would also be tightly bound to the binding site of 15-LOX-2, yielding a similar inhibition profile to the observed for conandroside.

The physicochemical descriptors, drug-likeness, pharmacokinetics and ADME (absorption, distribution, metabolism, and excretion) parameters (Figure S9, Supplementary Information) were predicted by using free SwissADME web tool. ${ }^{34-38}$ The analyses indicated that the conandroside is water-soluble, has low gastrointestinal absorption and is not BBB (blood-brain barrier) permeant. Regarding the drug-likeness potential, the conandroside showed violations with respect to the Lipinski, Ghose, Veber, Egan, and Muegge filters, suggesting a low oral bioavailability of this compound.

\section{Conclusions}

The LC-HRMS data and the bioactivity chromatogram of Arrabidaea brachypoda (DC.) Bureau (Bignoniaceae) ethanol crude extract, which showed inhibitory properties against LOX and was unable to affect normal cells in culture, was reported in this study. This initial information led to isolation of conandroside, which showed in vitro 15-LOX inhibitory activity and was not cytotoxic to normal cells. Docking studies with 15-LOX, isoform 2, indicated that the principal interactions for conandroside were hydrogen bonds with $\mathrm{His}^{373}, \mathrm{Leu}^{415}, \mathrm{Asp}^{602}, \mathrm{Ala}^{606}$ and $\mathrm{Ile}^{676}$, coordination with $\mathrm{Fe}^{3+}$ ion, $\pi-\pi$ interactions with $\mathrm{His}^{373}$ and $\mathrm{Phe}^{192}$ residues and a cation- $\pi$ interaction with $\mathrm{Arg}^{429}$. The main interactions for quercetin were H-bond with $\operatorname{Leu}^{415}, \pi-\pi$ and cation- $\pi$ interaction with His $^{373}$ and an indirect H-bond using a water molecule as bridge to connect its benzopyrone nucleus of the ligand with $\mathrm{His}^{373}$ and $\mathrm{Ile}^{676}$ from the active site. These results together suggest that conandroside could be explored as 
a lipoxygenase inhibitor, and the chemical structure can be investigated by chemical synthesis to obtain improved physicochemical and biological properties. Also, a pharmacological study of the crude extract in animal models of inflammation will confirm the in vitro crude extract activity.

\section{Supplementary Information}

HPLC-HRMS of crude extract, HPLC-DAD, NMR spectra of conandroside, and computed parameter values (bioavailability radar, physicochemical properties, lipophilicity, water-solubility, pharmacokinetics, druglikeness, and medicinal chemistry) for conandroside are available free of charge at http://jbcs.sbq.org.br as PDF file.

\section{Acknowledgments}

The authors are grateful to FAPESP (São Paulo Research Foundation) for financial support (grant 2013/09280-6). CNPq (The National Council for Scientific and Technological Development) is acknowledged for Research Productivity Fellowships granted to M. L. A. S., W. R. C., A. H. J., D. C. T., R. L. T. P. and P. M. P.; C. S. B. and V. M. M. G. were supported by CAPES scholarships.

\section{References}

1. Durigan, G.; Baitello, J. B.; Franco, G. A. D. C.; Siqueira, M. F.; Plantas do Cerrado Paulista: Imagens de uma Paisagem Ameaçada; Páginas \& Letras Editora e Gráfica: São Paulo, Brazil, 2004.

2. Rodrigues, E.; Mendes, F. R.; Negri, G.; Curr. Med. Chem. 2006, 6, 211.

3. da Rocha, C. Q.; Queiroz, E. F.; Meira, C. S.; Moreira, D. R.; Soares, M. B.; Marcourt, L.; Vilegas, W.; Wolfender, J. L.; J. Nat. Prod. 2014, 77, 1345.

4. da Rocha, C. Q.; Vilela, F. C.; Cavalcante, G. P.; Santa-Cecília, F. V.; Santos-e-Silva, L.; dos Santos, M. H.; Giusti-Paiva, A.; J. Ethnopharmacol. 2011, 133, 396.

5. Gentry, A. H.; Flora Neotropica, Monograph 25 (II); The New York Botanical Garden: New York, 1980.

6. Lohmann, L. G.; Bell, C. D.; Calió, M. F.; Winkworth, R. C.; Bot. J. Linn. Soc. 2013, 171, 154.

7. Lohmann, L. G.; Am. J. Bot. 2006, 93, 304.

8. Brandão, G. C.; Kroon, E. G.; Souza, D. E.; Souza Filho, J. D.; Oliveira, A. B.; Molecules 2013, 18, 9919.

9. Aro, A. A.; Simões, G. F.; Esquisatto, M. A.; Foglio, M. A.; Carvalho, J. E.; Oliveira, A. L.; Gomes, L.; Pimentel, E. R.; Injury 2013, 44, 884.
10. Jorge, M. P.; Madjarof, C.; Ruiz, A. L. G.; Fernandes, A. T.; Rodrigues, R. A. F.; Sousa, I. M. O.; Foglio, M. A.; de Carvalho, J. E.; J. Ethnopharmacol. 2008, 118, 361.

11. Mafioleti, L.; da Silva Jr., I. F.; Colodel, E. M.; Flach, A.; Martins, D. T.; J. Ethnopharmacol. 2013, 150, 576.

12. Michel, A. F.; Melo, M. M.; Campos, P. P.; Oliveira, M. S.; Oliveira, F. A.; Cassali, G. D.; Ferraz, V. P.; Cota, B. B.; Andrade, S. P.; Souza-Fagundes, E. M.; J. Ethnopharmacol. 2015, 165, 29.

13. Tafarello, D.; Jorge, M. P.; Sousa, I. M. O.; Duarte, M. C. T.; Figueira, G. M.; Queiroz, N. C. A.; Rodrigues, R. A. F.; Carvalho, J. E.; Goes, A. L. T. R.; Foglio, M. A.; Riveros, J. M.; Eberlin, M. N.; Cabral, E. C.; Quim. Nova 2013, 36, 431.

14. Brandão, H. N.; David, J. P.; Couto, R. D.; Nascimento, J. A. P.; David, J. M.; Quim. Nova 2010, 33, 1359.

15. Pauletti, P. M.; Castro-Gamboa, I.; Silva, D. H. S.; Young, M. C.; Tomazela, D. M.; Eberlin, M. N.; Bolzani, V. S.; J. Nat. Prod. 2003, 66, 1384.

16. Alvarenga, T. A.; Bêdo, T. R. F. O.; Braguine, C. G.; Gonçalves, U. O.; Magalhães, L. G.; Rodrigues, V.; Gimenez, V. M. M.; Groppo, M.; Silva, M. L. A.; Cunha, W. R.; Januário, A. H.; Pauletti, P. M.; Int. J. Biotechnol. Wellness Ind. 2012, 1, 122.

17. Alvarenga, T. A.; Bertanha, C. S.; de Oliveira, P. F.; Tavares, D. C.; Gimenez, V. M. M.; Silva, M. L.; Cunha, W. R.; Januário, A. H.; Pauletti, P. M.; Nat. Prod. Res. 2015, 29, 1083.

18. Haeggström, J. Z.; Funk, C. D.; Chem. Rev. 2011, 111, 5866.

19. Song, P.; Wang, Q.; Lv, J. N.; Xu, C.; Lin, Q. X.; Ma, X. H.; Huang, M.; Yang, X. Z.; J. Huazhong Univ. Sci. Technol., Med. Sci. 2015, 35, 450.

20. Jensen, S.; Phytochemistry 1996, 43, 777.

21. Jones, G.; Willett, P.; Glen, R. C.; J. Mol. Biol. 1995, $245,43$.

22. Jones, G.; Willett, P.; Glen, R. C.; Leach, A. R.; Taylor, R.; J. Mol. Biol. 1997, 267, 727.

23. Verdonk, M. L.; Cole, J. C.; Hartshorn, M. J.; Murray, C. W.; Taylor, R. D.; Proteins 2003, 52, 609.

24. Rodrigues, R. P.; Andrade, S. F.; Mantoani, S. P.; Eifler-Lima, V. L.; Silva, V. B.; Kawano, D. F.; J. Chem. Educ. 2015, 92, 827.

25. Accelrys Discovery Studio; Biovia, San Diego, 2016.

26. Suffness, M.; Pezzut, J. M. In Methods in Plant Biochemistry: Assays for Bioactivity, vol. 6; Hostettmann, K., ed.; Academic Press: London, UK, 1990, p. 71.

27. Nonaka, D.; Nishioka, I.; Phytochemistry 1977, 16, 1265.

28. Jensen, S.; Biochem. Syst. Ecol. 2000, 28, 45.

29. Keefover-Ring, K.; Phytochem. Lett. 2014, 10, 132.

30. Lee, J. H.; Kim, G. H.; J. Food Sci. 2010, 75, H212.

31. ElBordiny, H. S.; El-Miligy, M. M.; Kassab, S. E.; Daabees, H.; Ali, W. A. M.; El-Hawash, S. A. M.; Eur. J. Med. Chem. 2018, 145, 594.

32. Cabezas, F.; Mascayano, C.; J. Biomol. Struct. Dyn. 2019, 37, 1511. 
33. Kobe, M. J.; Neau, D. B.; Mitchell, C. E.; Bartlett, S. G.; Newcomer, M. E.; J. Biol. Chem. 2014, $289,8562$.

34. Daina, A.; Zoete, V.; Chem. Med. Chem. 2016, 11, 1117.

35. Daina, A.; Michielin, O.; Zoete, V.; J. Chem. Inf. Model. 2014, $54,3284$.
36. Daina, A.; Michielin, O.; Zoete, V.; Sci. Rep. 2017, 7, 42717.

37. El Kerdawy, A. M.; Osman, A. A.; Zaater, M. A.; J. Mol. Model. 2019, 25, 171.

38. http://www.swissadme.ch/index.php, accessed in October 2019.

Submitted: April 4, 2019

Published online: October 22, 2019 